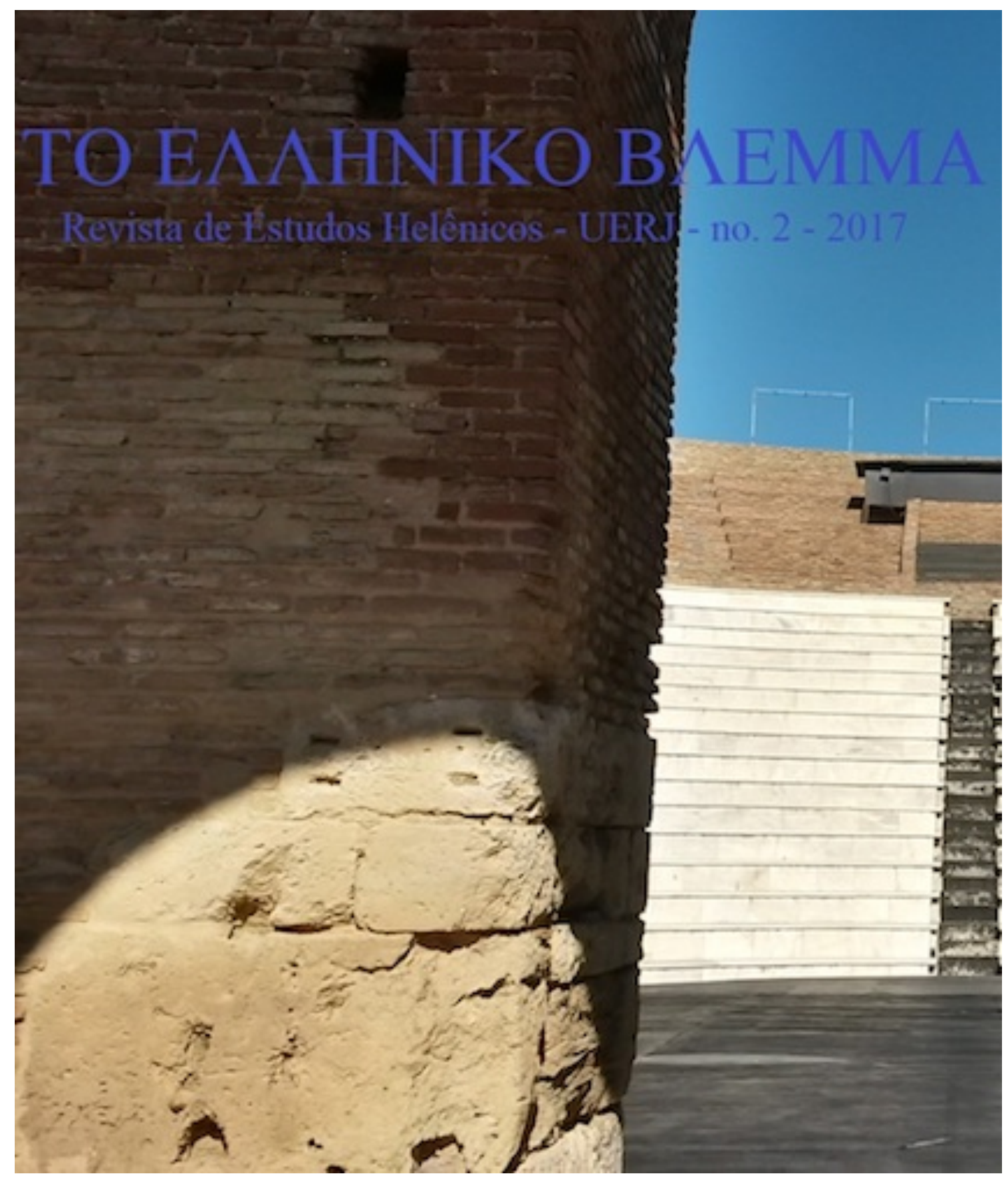




\title{
A apresentação de si de Paulo de Tarso diante dos Atenienses em seu discurso no Areópago de Atenas ${ }^{1}$
}

\author{
Luciene de Lima Oliveira - UERJ
}

\section{Resumo}

Ao anunciar a nova crença em sua jornada missionária, o apóstolo Paulo, antes perseguidor implacável dos seguidores de Jesus, pronunciou muitos e variados discursos, diante de públicos bastante heterogêneos, não só para difundir os seus ideais, mas também para participar de debates ou mesmo se defender de acusações religiosas e politicas que lhe iam sendo impostas. Assim é que o presente artigo buscará identificar qual a imagem, diga-se, apresentação de si que Paulo de Tarso construiu diante do seu público para obter a persuasão dos atenienses de que o "Deus Desconhecido", a quem os gregos veneravam era o verdadeiro Deus e, somente, a essa divindade deveriam cultuar. Ressalte-se que a noção de ท̂ंos êthos provém da retórica de Aristóteles (ARISTOTE. Rhétorique

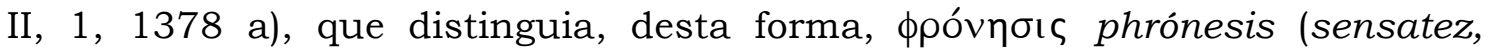
prudência, isto é, ter o aspecto de pessoa ponderada), ỏpetŕ, areté (isto é, assumir a atitude de um homem de fala franca), عưvoı a, eúnoia (boa vontade, benevolência, isto é, oferecer uma imagem agradável de si mesmo). Ora, a questão de êthos foi reformulada na psicologia social, em termos de apresentação de si, devido aos trabalhos de pesquisadores como Goffman (KERBRAT-ORECCHIONI apud MACHADO \& MELLO, 2010, p. 117).

Palavras-chave: Retórica, Êthos, Apóstolo Paulo, Areópago de Atenas

\section{PAUL OF TARSUS' SELF-PRESENTATION \\ BEFORE THE ATHENIEN PEOPLE IN HIS SPEECH IN THE AREOPAGUS IN ATHENS}

\begin{abstract}
When announcing his new belief in his missionary journey, the apostle Paul, who had been relentless persecuter of Jesus followers, uttered several and varied speeches, before a very heterogeneous audience, not only to disseminate his ideals, but also to participate in debates or even defend himself from religious and political imposed allegations. The present research will pursue identifying to which image, I mean, self-presentation Apostle Paul has built before his audience in order to obtain the athenian's persuasion that the "Unknown God", to whom the Greek worshipped, was the true God and that they should worship only this deity. It is important to stress that the notion of î $\theta 0 \varsigma$, ethos, is provided from Aristhotle's rhetoric (ARISTOTE. Rhétorique II, 1,
\end{abstract}

\footnotetext{
${ }^{1}$ O presente artigo constitui uma adaptação da monografia intitulada A Apresentação de Si de Paulo de Tarso diante dos Atenienses em seu Discurso no Areópago de Atenas, apresentada à Profa. Doutora Lúcia H. Martins Gouvea na disciplina Questões de Pragmática (LEV 819) em 2011/1, no Programa de Pós Graduação em Letras da UFRJ. Convém sublinhar, ainda, que o artigo também é uma adaptação do capítulo 6 da Tese de Doutorado intitulada Os Discursos Epidícticos de Paulo de Tarso no Livro dos Atos dos Apóstolos (Tradução e Comentários), defendida em fevereiro de 2016, sob a orientação do Professor Doutor Auto Lyra Teixeira no PPGLC da UFRJ.
} 


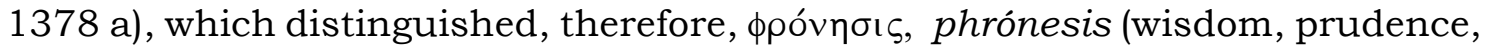
namely, having the aspecto of a balanced person), ảpeтŕ, areté (virtue, namely, presenting the atitude of a man with honest speech), عúvoı $\alpha$, eúnoia (good will, kindness, namely, offering the image of pleasant with his/her own self). Now, the issue of êthos has been redesigned in social psychology, in terms of selfpresentation, according to the works of researchers such as Goffman (KERBRAT-ORECCHIONI apud MACHADO \& MELLO, 2010, p. 117).

Keywords: Rethoric, Ethos, Apostle Paul, Areopagus in Athens.

Todo ato de tomar a palavra implica a construção de uma imagem de si. Para tanto, não é necessário que o locutor faça seu autorretrato, detalhe suas qualidades nem mesmo fale explicitamente de si. Seu estilo, suas competências linguísticas e enciclopédicas, suas crenças implícitas são suficientes para construir uma representação de sua pessoa. Que a maneira de dizer induz a uma imagem que facilita ou mesmo condiciona a boa realização do projeto (...). (Ruth Amossy)

\section{Notas Introdutórias}

A linguagem é inerente ao homem, que permite ao homem pensar, agir e viver em sociedade. Sem a posse da linguagem, o ser humano não saberia como entrar em contato com o outro, como estabelecer vínculos psicológicos e sociais com esse outro que é, simultaneamente, semelhante e diferente. A linguagem, talvez, seja o primeiro poder do homem. Todavia, esse poder da linguagem é o próprio homem que constrói e que ajusta por meio de suas trocas, seus contatos no decorrer da história dos povos. Além do mais, a argumentação é um setor de atividade da linguagem que sempre exerceu fascínio. A propósito, desde a retórica dos antigos fizeram dela o próprio fundamento das relações pessoais ( $a$ arte de persuadir) (CHARAUDEAU, 2010, p. 7).

O presente artigo buscará identificar qual a imagem, diga-se, apresentação de si que Paulo de Tarso construiu diante do seu público em seu discurso no Areópago de Atenas ${ }^{2}$, para obter a persuasão dos atenienses de que o "Deus Desconhecido", a quem os gregos veneravam era o verdadeiro Deus e, somente, a essa divindade deveriam cultuar.

Sabe-se que os estudiosos não são unânimes quanto à formação retórica de Paulo, mas a maioria concorda que o religioso era detentor de uma ampla cultura, seja judaica ou greco-romana, e, possivelmente, poliglota. De qualquer forma, dois lugares surgem como possíveis onde o apóstolo teria obtido a sua formação retórica: Tarso ou Jerusalém.

Fabris destaca que nas grandes cidades, onde Paulo anunciava o evangelho, ele fale o grego, que é a lingua franca de comunicação em todo o

\footnotetext{
${ }^{2}$ A propósito, esse discurso de Paulo de Tarso se encontra registrado no livro de Atos dos Apóstolos, que foi redigido em grego koiné, provavelmente, entre 61 e 63 d.C.
} 
Império Oriental. Embora Paulo seja de língua materna hebraica ${ }^{3}$, ele teria aprendido o grego como segunda língua não só na escola como também no contexto de sua primeira formação na cidade de Tarso (FABRIS, 1996, p. 33).

Ora, da leitura dos escritos de Paulo, tem-se a impressão de que ele se move com desenvoltura no ambiente cultural greco-romano. Em tal contexto, explica-se também a afinidade de alguns excertos de Paulo com os modelos expressivos do debate ou diatribe em uso entre mestres e propagandistas do estoicismo popular (FABRIS, 1996, p. 33).

A narrativa dos Atos diz que Paulo estava em Atenas esperando Silas e Timóteo 4 e, enquanto esperava, ficou revoltado em face da "idolatria" da cidade e, consequentemente, do politeísmo grego; na sinagoga, ele passou a discutir com judeus e gentios piedosos, assim como também na ágora, dirigindo-se, diariamente, aos que ali se encontravam (At 17. 16-21).

Não obstante, alguns dos filósofos epicureus e estóicos que debatiam com Paulo, que estava pregando a Jesus e à ressurreição, o retiveram consigo e o levaram ao Areópago. Na verdade, os filósofos queriam saber que nova doutrina era aquela de que Paulo tanto falava. Paulo, então, ficou de pé no Areópago para discursar (At 17. 21-22).

Convém lembrar que a maioria dos filósofos de Tarso, cidade natal de Paulo, eram estóicos como Atenodoro de Tarso. É bem provável que Paulo, quando criança, tivesse ouvido falar de Atenodoro, pois esse morrera em 7 d.C. Paulo, em certa ocasião, chamou a atenção para os perigos das filosofias religiosas gregas $(\mathrm{Cl} 2.8)$.

A propósito, Jaeger considera a visita do apóstolo a Atenas, um centro intelectual e cultural do mundo grego clássico, como sendo um momento decisivo no encontro entre gregos e cristãos: "Pode ser que Lucas tinha a intenção de dramatizar por meio desse acontecimento a luta intelectual entre o cristianismo e o mundo clássico" (JAEGER, 1965, p. 23).

A kérygma cristã falava da ignorância dos homens, prometia dar-lhes um conhecimento melhor e, como todas as filosofias, fazia referência a um mestre que possuía e revelava a verdade. Esta situação paralela entre os filósofos gregos e os missionários cristãos levou a estes últimos a aproveitá-la em seu favor (JAEGER, 1965, p. 21).

Na verdade, o politeísmo poderia ser objeto de tolerância; entrementes, cabia aos homens acolher a pregação cristã, quando chegasse até eles, a fim de

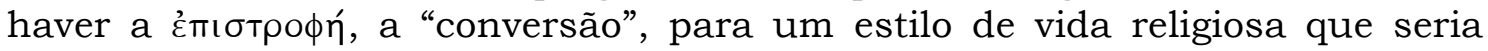
considerada correta. Na concepção judaico-cristã, tratava-se de chamar a atenção para o "erro da idolatria", alicerçado na representação imagética das divindades (Dt 5. 7-9; Lv 17. 7-9; Am 2. 4; Jr 10. 1-16; Ez 8. 10).

Inicialmente, foram feitas as traduções dos excertos paulinos alicerçadas no texto grego The Greek New Testament de Kurt Aland et alii, $4^{\text {a }}$ edição revisada, texto editado pela Sociedade Bíblica do Brasil.

\footnotetext{
${ }^{3}$ Presume-se que Fabris estivesse se referindo ao aramaico palestinense.

${ }^{4}$ Pode-se até dizer que a estadia de Paulo em Atenas fora, praticamente, por um acaso, uma vez que estava esperando dois companheiros que tiveram de sair às pressas de Bereia (At 17. 13-15) e fazer os preparativos para a viagem a Corinto.
} 


\section{Pressupostos Teóricos}

A questão de êthos foi reformulada na psicologia social e em microssociologia, em termos de apresentação de si, devido aos trabalhos de pesquisadores como Goffman (KERBRAT-ORECCHIONI apud MACHADO \& MELLO, 2010, p. 117).

O discurso é inseparável de uma "voz"; essa era uma dimensão bem conhecida da retórica antiga, que entendia por $\eta \hat{\eta} \theta$, éthe, as propriedades, isto é, a imagem que um orador transmitia, implicitamente de si mesmo, através de sua maneira de falar: adotando as entonações, os gestos, o porte geral de um homem honesto, por exemplo, não se diz, explicitamente, que se é honesto, mas isso é mostrado. Assim é que, o emissor, através do discurso, ativa no destinatário uma construção de uma representação de si, que o locutor se esforça por controlar de modo mais ou menos consciente (MAINGUENEAU, 2006, p. 59; apud MACHADO \& MELLO, 2010, p. 193) $)^{5}$

$\mathrm{Na}$ verdade, o enunciador deve se conferir, e conferir a seu destinatário, certo status para legitimar seu dizer: ele se outorga no discurso uma posição institucional e marca sua relação com um saber. (...) A maneira de dizer autoriza a construção de uma verdadeira imagem de si e, na medida em que o locutário se vê obrigado a depreendê-la a partir de diversos indices discursivos, ela contribui para 0 estabelecimento de uma inter-relação entre o locutor e seu parceiro. Participando da eficácia da palavra, a imagem quer causar impacto e suscitar adesão. Ao mesmo tempo, o êthos está ligado ao estatuto do locutor e à questão de sua legitimidade, ou melhor, ao processo de sua legitimação pela fala (MAINGUENEAU apud AMOSSY, 2011, p. 16-17).

A apresentação de si não está limitada a uma técnica que se aprende, a um artificio, uma vez que ela se efetua, muitas vezes, "à revelia dos parceiros, nas trocas verbais mais corriqueiras e pessoais" (AMOSSY, 2011, p. 9).

O êthos está ligado à enunciação, não a um saber extradiscursivo sobre o enunciador (MAINGUENEAU apud AMOSSY, 2011, p. 70).

Por meio da enunciação, revela-se a personalidade do enunciador. Roland Barthes salientou a característica essencial desse êthos: "São os traços de caráter que o orador deve mostrar ao auditório (pouco importa sua sinceridade) para causar boa impressão: são os ares que assume ao se apresentar" (BARTHES apud MAINGUENEAU, 2004, p. 98).

Catherine Kerbrat-Orecchioni destaca que a imagem que o orador constrói através de seu discurso é a imagem sobre a qual se fundamenta, em grande parte, tanto o sucesso quanto o fracasso da persuasão. A esse êthos, a pesquisadora denomina de êthos-1, êthos individual (KERBRAT-ORECCHIONI, 2010, p. 118). Já o êthos-2 é a caracterização do comportamento de uma

\footnotetext{
${ }^{5} \mathrm{Na}$ realidade, mesmo os corpus escritos não constituem uma oralidade enfraquecida, mas algo dotado de uma "voz", a de um sujeito situado para além do texto. Embora o texto seja escrito, ele é sustentado por uma voz específica: "a oralidade não é o falado", como lembra Meschonnic (MESCHONNIC apud MAINGUENEAU, 1997, p. 46).
} 
coletividade, "identificada, na maior parte dos estudos a uma "cultura" vista em sua globalidade" (ibidem, 2010, p. 125).

A noção de êthos provém da retórica de Aristóteles (ARISTOTE.

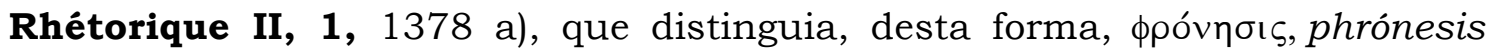
(sensatez, prudência, isto é, ter o aspecto de pessoa ponderada), ỏpetŕ, areté (virtude, isto é, assumir a atitude de um homem de fala franca), cưvoı a, eúnoia (boa vontade, benevolência, isto é, oferecer uma imagem agradável de si mesmo).

O orador, que tem o $\hat{\jmath} \theta$ os, êthos, formado por estas três qualidades, possui a confiança do ouvinte (ARISTOTE. Rhétorique II, 1, 1378 a 6-19).

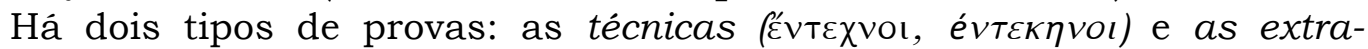

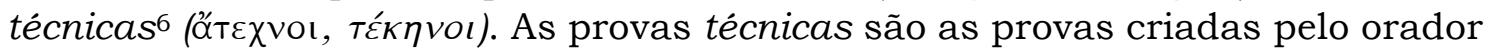
com o objetivo de persuadir o auditório. Ressalte-se que as provas técnicas empregadas através do discurso são de três espécies:

a) Quanto ao êthos do orador, uma vez que se pode alcançar a persuasão pelo êthos do orador, quando o discurso é dito de tal sorte que "torne o orador digno de crédito. (...) Mas é necessário que esta confiança seja o efeito do discurso, não de um juízo prévio sobre o êthos do orador" (ARISTOTE. Rhétorique I, 2, 1356 a 5).

b) Quanto aos afetos, páthe dos ouvintes, quando o discurso os leva a sentir algo (ARISTOTE. Rhétorique I, 15, 1356 a 14)7. A eúnoia diz respeito ao páthos, pois se trata de um afeto, uma vez que mostra ao ouvinte que o orador é bem intencionado para com ele (EGGS apud AMOSSY, 2011, p. 33).

c) Quanto ao valor demonstrativo do discurso, Aristóteles pontua que o discurso (dià tòn lógon) gera a persuasão, quando a verdade e o verossímil são mostrados (ARISTOTE. Rhétorique, I, 2, 1356 a 19-20).

Eggs destaca que o lugar que engendra o êthos é o discurso, lógos do orador, e esse lugar é mostrado através das escolhas feitas pelo orador, uma vez que "toda forma de se expressar" é produto de uma escolha entre outras possibilidades linguísticas e estilísticas (EGGS apud AMOSSY, 2011, p. 31).

Charaudeau sublinha que convém que os sujeitos falantes ganhem em credibilidade diante do seu público. Assim, o sujeito falante é levado a apostar na influência, se baseando em quatro estratégias discursivas, a saber: 1) "o modo de estabelecimento de contato com o outro e o modo de relação que se instaura entre eles; 2) a construção da imagem do sujeito falante (seu êthos); 3) a maneira de tocar o afeto do outro para seduzi-lo ou persuadi-lo (o páthos) e 4) os modos de organização do discurso que permitem descrever o mundo e explicá-lo segundo os princípios da veracidade (o lógos)" (CHARAUDEAU apud MACHADO \& MELLO, 2010, p. 59).

A argumentação está baseada em uma relação triangular entre um sujeito argumentante, uma proposta sobre o mundo e um sujeito-alvo (idem, 2010, p. 205). A proposta do pesquisador francês é bem parecida com a de Aristóteles que sublinha que o discurso consta de três componentes (ARISTOTE. Rhétorique I, 3, 1358 a 37-40): a) o que fala (o orador); b) aquilo que se fala (o assunto); c) aquele a quem se fala (o auditório).

\footnotetext{
${ }^{6}$ Já as provas extra-técnicas não são criadas pelo orador, citem-se, por exemplo: as testemunhas, os escritos, as confissões sob tortura. Aristóteles enfatiza que as testemunhas são de duas espécies: as testemunhas antigas e as recentes (ARISTOTE. Rhétorique I, 15, 1375 b 26-34 / 1376 a 1-16). Denominam-se testemunhas antigas os poetas e outros personagens.

7 Os afetos/emoções são "os meios pelos quais se fazem mudar os homens nos seus juízos e que têm por consequência o prazer e a dor como, por exemplo, a cólera, a compaixão, o temor e todas as outras emoções semelhantes e aquelas que são contrárias" (ARISTOTE. Rhétorique II, 1, 1378 a 20-22).
} 
Como destaca Reboul: "para ser bom orador, não basta saber falar; é preciso saber também a quem se está falando, compreender o discurso do outro, seja esse discurso manifesto ou latente, detectar suas ciladas, sopesar a força de seus argumentos e, principalmente, captar o não-dito" (REBOUL, 2004, p. $\mathrm{XIX).}$

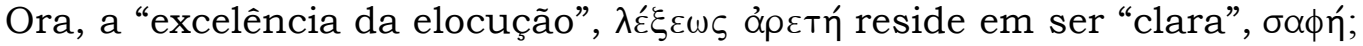
sinal disso é que, se o discurso não for claro, não alcançará o seu objetivo. Além

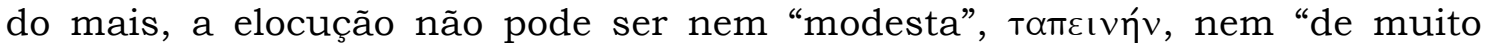

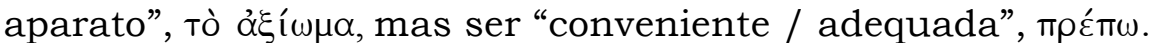

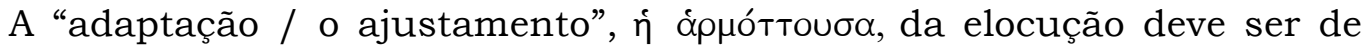
acordo com cada "gênero / categoria", yévos, e "disposição / maneira de ser",

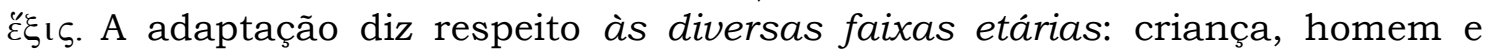
ancião; ao sexo: feminino ou masculino; à nação: lacônio ou tessálio. Já a

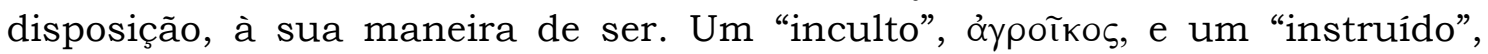
$\pi \varepsilon \pi \alpha ı \delta \varepsilon u ́ \mu \varepsilon v o \varsigma$, não falam, igualmente, as mesmas palavras, valendo-se de diferentes registros (ARISTOTE. Rhétorique III, 7, 1408 a 25-32).

É bom lembrar que a adaptação do auditório não diz respeito, somente, à questões vinculadas à linguagem, uma vez que não basta que o auditório compreenda o que o orador diz, mas, para persuadir o auditório, deve-se, em primeiro lugar, conhecê-lo, isto é, conhecer "as teses que ele admite de antemão e que poderão servir de gancho à argumentação" (PERELMAN, 2004, pp. 145146).

O mais importante não é conhecer aquilo que o orador considera como verdadeiro ou probatório, mas "qual é o parecer daquele a quem a argumentação se dirige". O orador pensa de modo mais ou menos consciente em relação aos ouvintes que se procura persuadir e que constituem o auditório em que seus discursos são dirigidos. Haja vista que o conhecimento prévio daqueles a quem se quer persuadir é, na verdade, uma condição importante de uma argumentação eficaz.

Deve-se pensar nos tipos de argumentos que podem influenciar o interlocutor; preocupar-se com ele e interessar-se por seu estado de espírito (PERELMAN, OLBRECHTS-TYTECA, 2005, pp. 18-27).

Assim é que a análise da argumentação gira em torno do que seja, presumidamente, admitido pelo auditório. Os pesquisadores, ainda, pontuam que "tanto o desenvolvimento como o ponto de partida da argumentação pressupõe acordo do auditório (...)". A propósito, determinados argumentos considerados válidos para certas pessoas podem não ser, de modo absoluto, para outras (ibidem, p. 73, 117).

Ruth Amossy, ao fazer uma análise do pensamento de Perelman destaca que o orador apoia seus argumentos levando em consideração a dóxa que toma emprestado de seus ouvintes. Assim, o orador constrói a sua imagem em função da imagem que ele tem de seu auditório, "das representações do orador confiável e competente que ele crê ser as do público" (AMOSSY, 2011, p. 124).

Entrementes, Glad dá o seguinte testemunho sobre Paulo e a "adaptalidade":

A ideia da adaptalidade era comum no mundo grecoromano no tempo de Paulo entre diferentes segmentos da sociedade por toda a bacia do Mediterrâneo. "Adaptação" é um termo relacional; fala-se de adaptar ou ajustar alguma coisa a outra, por exemplo, seu comportamento ou sua fala aos outros em circunstâncias específicas. Como conceito relacional, o termo se refere ao que precisa ser adaptado e àquilo a que precisa se adaptar. Relaciona-se com o caráter, 
a obra e os objetivos de alguém, e com as várias circunstâncias e tipos de pessoas que se encontram. A adaptação no discurso, muitas vezes tratada sob os títulos de propriedade do discurso e descrição de caráter, tinha de atuar nas várias condições dos destinatários numa tentativa de ser perspicaz. Os retóricos sabiam muito até que ponto sua apresentação podia afetar a recepção de seus discursos. Os oradores tinham de saber como falar adequadamente no "momento oportuno" para obter o desejado impacto nos ouvintes (GLAD apud SAMPLEY, 2008, pp. 1-3).

A propósito, a opinião de Glad é, também aqui, digna de nota:

Nesse modo de pensar, a "cooptação ou "empréstimo" que Paulo faz de concepções, convenções ou práticas helenísticas ou romanas era, simplesmente, sua maneira criativa de embalar o evangelho. Longe de mim dizer que Paulo não era oportunista! Servia-se de qualquer abertura, oportunidade ou situação que se apresentava como ocasião de pregar. Por exemplo a sua pregação aos gálatas, justamente porque ficou doente enquanto atravessava a terra deles (Gl 4. 13), ou sua pregação aos guardas pretorianos, porque aconteceu que eram eles que o vigiavam no cativeiro (Fp 1. 13) (GLAD apud SAMPLEY, 2008, p. XVII).

Há uma necessidade em considerar o êthos judaico de Paulo8 e, simultaneamente, seu êthos greco-romano", já que "todos os judaísmos na época do início do Cristianismo já estão helenizados; já estão marcados até certo ponto pelo onipresente influxo do mundo greco-romano e por seu êthos".

O mundo greco-romano era o mundo de Paulo, e por isso, não se pode dizer que Paulo "tomou emprestada" esta ou aquela tradição, convenção ou prática romana; do mesmo modo, não se deve utilizar expressões que sugiram que o apóstolo esteja "adotando" os modos característicos de um romano. Por consequência, Paulo apresenta-se, de fato, como um judeu, e um judeu romano, no ecúmeno do Mediterrâneo Oriental de sua época. Assim é que Paulo conhece, de modo perfeito, as convenções e as práticas de seu tempo (SAMPLEY, 2008, pp. XVI-XVIII).

Já Fiorin argumenta que o falante organiza sua estratégia discursiva em função da imagem que ele tem do interlocutor, em função da imagem que ele pensa que o interlocutor tem dele e, por fim, em função da imagem que ele deseja transmitir ao interlocutor. Assim, devido a esse jogo de imagens, o falante utiliza determinados procedimentos argumentativos e não outros (FIORIN, 2003, p. 18).

Sublinhe-se que a obra Linguagem e Discurso: Modos de Organização de

\footnotetext{
8 A expressão "Eu sou varão judeu" (...) (At 22. 3) constitui uma declaração de uma identidade, apontando para a fidelidade de Paulo quanto ao judaísmo. Por meio do reforço do pronome pessoal e do verbo no presente, na primeira pessoa do discurso, "eu sou ", Paulo apresenta informações do âmbito étnico-religioso. A propósito, não só essa expressão, mas também a referência ao seu curriculum vitae, onde inclui a escola de Gamaliel em Jerusalém (At 22. 3), assim como as cartas que recebeu para perseguir os cristãos de Damasco (At 22. 5) são, aqui, elementos fundamentais para a apresentação de sua identidade diante dos ouvintes. Assim sendo, Paulo adapta o seu $\mathrm{h}^{\wedge} \mathrm{qo} \uparrow$ diante de seu público hierosolimitano.

9 Ver, sobretudo, At 17. 28.
} 
Patrick Charaudeau foi de suma importância para a análise do discurso paulino no Areópago de Atenas.

\section{Comentários}

Levando em consideração os pressupostos teóricos supracitados de vários pesquisadores e tomando por base as três etapas da argumentação: 1) o começo; 2) a transição; 3) o fim, propostas por Charaudeau (CHARAUDEAU, 2010, p. 244-245), pode-se fazer as seguintes observações a respeito do discurso paulino no Areópago de Atenas.

O Começo: é a exposição dos elementos da Proposta e da Proposição

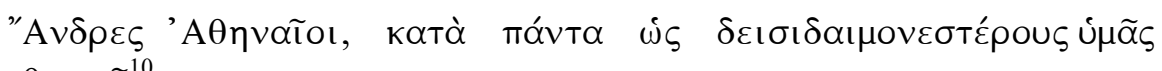
$\theta \varepsilon \omega \rho \widetilde{\omega}^{10}$.

Ó varões atenienses, de acordo com todas as coisas, vejo-vos como extremamente religiosos. (vers. 22)

Atesta-se, nesse discurso, o emprego de uma expressão em vocativo -

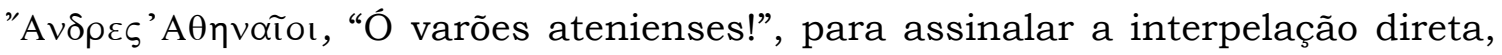
qualificando o orador o público específico a quem se dirige.

Após a invocação, segue-se a partícula w\&\&, aqui traduzida por "como", antecedendo e acentuando a forma do comparativo do adjetivo $\delta \varepsilon ı \sigma ı \alpha$ ı́ $\mu \omega v$ :

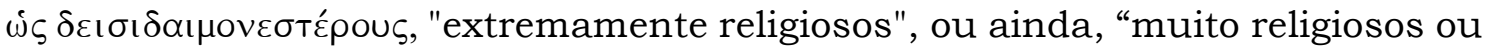
religiosos demais".

Desse modo, podem-se destacar determinados procedimentos discursivos utilizados por Paulo neste discurso como, por exemplo, a comparação

Rowe destaca que Atos 17. 22 é visto por estudiosos modernos como um exemplo excelente de captatio benevolentiae com o qual oradores antigos abriam os seus discursos. O destaque vai para o adjetivo no grau comparativo

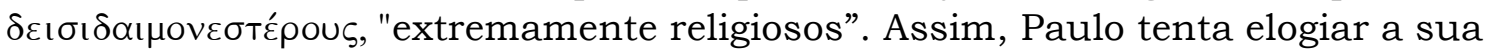
audiência e ganhar a sua $\varepsilon u ̛ v o ı$, "boa vontade" (ROWE, 2009, p. 33).

De modo inverso, outros estudiosos notam, claramente, o senso pejorativo que $\delta \varepsilon \iota \sigma ı \alpha \iota^{\prime} \mu \omega v$ pode levar no mundo antigo, e interpretam a sentença não como um procedimento retórico, mas como uma crítica de Paulo ao politeísmo ateniense. Esta leitura aponta para os Atos 17.16, onde Lucas, explicitamente, declara que Paulo estava revoltado por causa da "idolatria" da cidade e, em Atos 17. 30, Paulo caracteriza a "idolatria" ateniense como a!gnoia (At 17. 23) (ROWE, 2009, p. 33).

É bom lembrar que, para o estagirita, "o elogio é um discurso que mostra

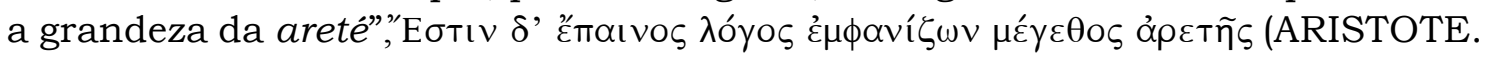
Rhétorique I, 9, 1367 b 27).

Não obstante, Aristóteles utiliza o vocábulo eỉkúv para expressar a semelhança, a imagem, a comparação entre elementos. Aristóteles ainda

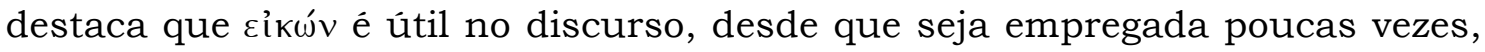
uma vez que é peculiar da poesia (ARISTOTE. Rhétorique III, 4, 1406 b 24-25).

Charaudeau pontua que "no âmbito de uma argumentação, a comparação é utilizada para reforçar a prova de uma conclusão ou de um

\footnotetext{
${ }^{10}$ Vine atesta que $\theta \varepsilon \omega \rho \varepsilon ́ \omega$, "vejo", é utilizado para fazer referência a alguém que olha uma determinada coisa com interesse e também com um propósito, indicando, então, uma observação minuciosa dos detalhes (VINE, 2002, p. 502).
} 
julgamento (...)" (CHARAUDEAU, 2010, p. 237). A comparação no prólogo de Paulo é, na terminologia charaudeana, denominada de "comparação objetiva, uma vez que o "comparante é verificável" (ibidem, p. 238).

Vanoye expressa que a "comparação completa compreende quatro termos" (VANOYE, 1986, p. 49):

1. O Comparado (objeto que se compara)

2. O Comparante (objeto ao qual se compara o comparado)

3. O Termo Comparativo: como, tal, tão, como, semelhante etc.

4. O Ponto de Comparação

\section{Estrutura da Comparação}

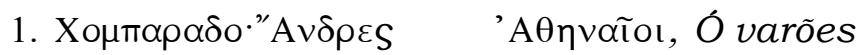
atenienses

2. Comparante: $\delta \varepsilon ı \sigma ı \alpha \iota \mu о v \varepsilon \sigma \tau \varepsilon ́ p o u s$, extremamente religiosos

3. Termo Comparativo: ws, como

4. Ponto de Comparação: A religiosidade dos atenienses

2) A Transição: Passa de um momento da argumentação a um outro.

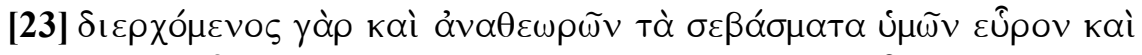

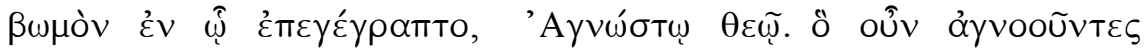

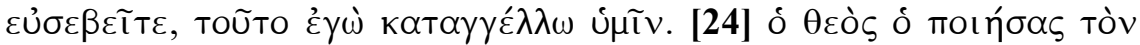

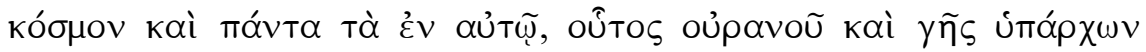

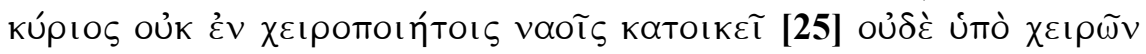

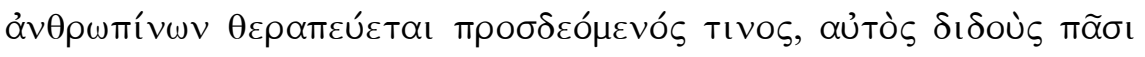

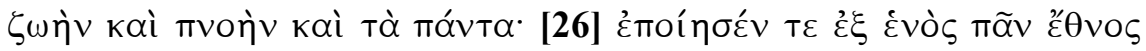

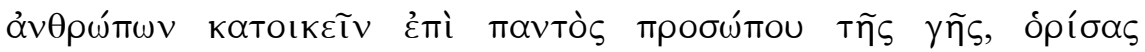

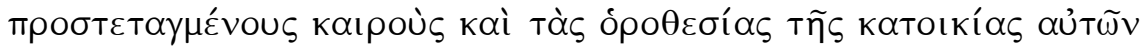

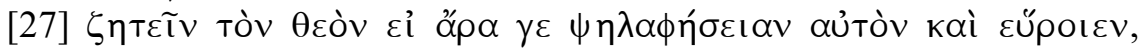

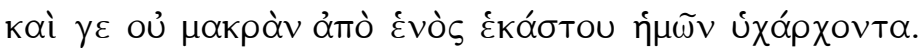

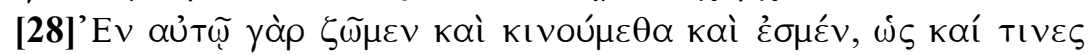

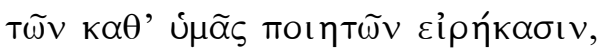

Toũ yò

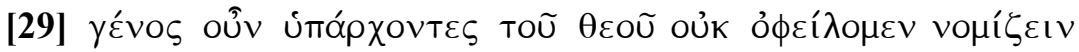

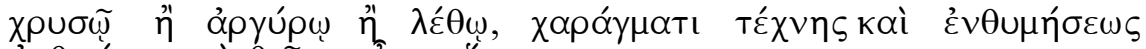

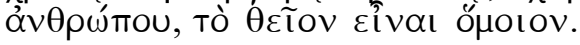

[23] Pois, passando e observando atentamente os vossos objetos de culto, encontrei também um altar, no qual estava escrito: "Ao Deus Desconhecido". Por conseguinte, aquilo que, não conhecendo, adorais, isto eu anuncio a vós. [24] O Deus que criou o Universo e todas as coisas (existentes) nele, esse, sendo Senhor do céu e da terra, habita, não em templos feitos por mãos humanas, [25] nem mesmo é servido por mãos típicas de homens, (como que) necessitando de alguma coisa. Dando ele a todos vida terrena e fôlego e todas as coisas. [26] E fez de um toda a raça de seres humanos para habitar sobre toda a face da terra; determinando tempos oportunos estabelecidos e os limites assinalados da 
habitação deles, [27] para buscarem a Deus, se porventura, pudessem tocá-lo e encontrassem, se bem que não esteja distante de cada um de nós.

[28] De fato, nele, vivemos e nos movemos e existimos, como também alguns dentre os vossos poetas falaram:

Também, com efeito, somos descendência dele.

[29] Por conseguinte, sendo descendência de Deus, não devemos pensar que a divindade seja semelhante à imagem de ouro ou a objeto de prata ou de pedra trabalhada, imagem de arte gravada e imaginação de ser humano.

Tem-se a utilização da conjunção explicativa yóp, "pois", para Paulo passar de um tópico da argumentação a outro e dar início à explicação do porquê do seu elogio: "Pois, passando e observando atentamente os vossos objetos de culto, encontrei também um altar, no qual estava escrito: "Ao Deus Desconhecido". Por conseguinte, aquilo que, não conhecendo, adorais, isto eu anuncio a vós" (vers. 23).

Sem dúvida, estava muito inspirado o apóstolo Paulo, ao usar um objeto de culto dos atenienses - o altar do "Deus Desconhecido", para tentar persuadir os atenienses da existência de um único Deus verdadeiro. $\mathrm{Na}$ verdade, o altar do "Deus Desconhecido" possuía uma história que tanto Paulo quanto os filósofos bem sabiam. O historiador Diógenes Laércio conta que Epimênides foi chamado a ir para Atenas, quando a cidade enfrentava uma grave peste. Quando chegou à cidade, expiou-a da seguinte forma: ordenou que soltassem um rebanho de ovelhas negras e brancas no Areópago; o lugar onde esses animais parassem para repousar era o local onde deveriam prestar culto à divindade. Assim, a praga cessou (DIÓGENES LAERCIO, Vidas de Filósofos Ilustres I, 2). Possivelmente, foi esse altar ao "Deus Desconhecido" que Paulo viu ${ }^{11}$.

Mesmo na época clássica, os poetas parecem inventar novos deuses, tais como, a Esperança, o Medo e outros conceitos que podem ser elevados a deuses, sabe-se que São Paulo considerou os atenienses "muito tementes a deus", todavia esse temor compreendia uma multiplicidade de deuses. Ao que tudo indica, tanto os gregos antigos quanto outros povos primitivos pensaram a mesma coisa a respeito dos deuses, uma vez que tinham a concepção de que a vida deles estava sujeita a poderes externos que eram incapazes de dominar, e a esses poderes denominaram de $\theta \varepsilon o$ í, deuses ${ }^{12}$. A todos os deuses deviam-se oferecer sacrificios, uma vez que qualquer irregularidade poderia irritá-los. É bem que verdade para os sacrificios, o homem deveria se submeter à purificação. Uma religião politeísta como a dos gregos é hospitaleira para novos deuses, uma raça grega que se instalasse em outro local continuaria venerando suas divindades e também as já existentes na região (KITTO, 1980, p. 323-329).

Um outro procedimento discursivo atestado é a definição de um ser (versículos 24 a 27). Para Charaudeau, no que diz respeito à argumentação, utiliza-se a definição com fins estratégicos, consistindo em descrever determinados traços semânticos que caracterizam um vocábulo, em certo contexto (CHARAUDEAU, 2010, p. 36).

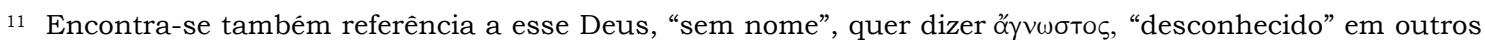
autores (DIOGENES LAERTIUS, Lives of Eminent Philosophers 1. 110); TERTULLIAN. Contre Marcion, I. 9; PAUSANIAS. Description of Greece I.1.4; V.14.8; FLAVIUS PHILOSTRATUS. The Life of Apollonius VI, 3).

${ }_{12}$ É bom lembrar sobre o que Paulo expressou, em uma de suas epístolas, a respeito da pluralidade de deuses (1 Co 8. 5-6).
} 
Dos versículos 24 ao 27, tem-se informações a respeito desse "Deus Desconhecido. O apóstolo sustentou seus argumentos empregando também

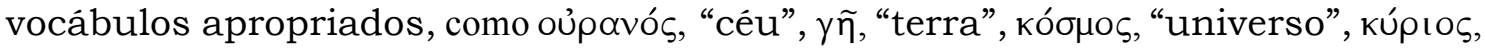

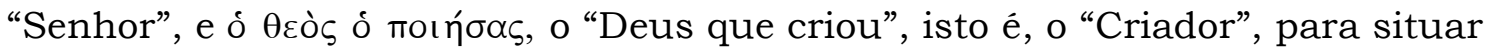
o "Deus Desconhecido", diante dos atenienses e para dar ênfase às obras criacionistas dessa Divindade. Através destas expressões, Paulo ratifica o poderio e a amplitude desse "Deus Desconhecido".

No início de Gênesis, em todo o primeiro capítulo, há a concepção judaica-cristã da criação do universo (Gn 1. 1-26). Ora, como exemplo da concepção grega da criação do universo, pode-se extrair preciosas informações da teogonia hesiótica, em que o poeta Hesíodo invoca às Musas (HESÍODO. Teogonia, vv. 104-110; 116-117; 126-128).

Paulo demonstrou que a Divindade, que ele anunciava, não dependia de sua criação humana e, mostra, mais uma vez, sua grandiosidade. Para dar mais realce às suas palavras, Paulo usa a partícula negativa oủ $\delta$, "nem mesmo". A antítese, nesse versículo 25, é entre a Deidade e o ser humano. A propósito, essa oposição se inicia no versículo 24, se estendendo até o versículo 27.

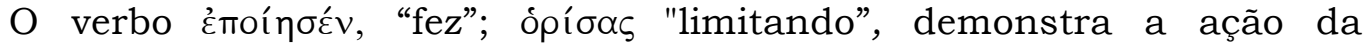

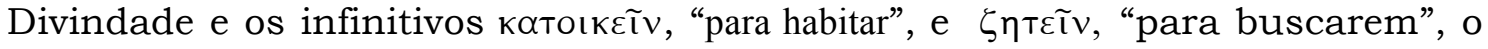
objetivo da Divindade com relação à sua criação, conforme os versículos 26-27.

Pela primeira vez, nesse discurso, Paulo emprega o "nós inclusivo" de "identificação", por meio do pronome pessoal de primeira pessoa do plural in $\mu \tilde{\omega} v$, “de nós" (vers. 27).

A citação é um outro procedimento discursivo, que Charaudeau denomina de "discurso relatado":"a citação consiste em referir-se, o mais fielmente possivel, (ou pelo menos dando uma impressão de exatidão) às emissões escritas ou orais de um outro locutor (...). A citação funciona como uma fonte de verdade, testemunho de um dizer, de uma experiência, de um saber" (CHARAUDEAU, 2010, p. 240).

Maingueneau chama de intertextualidades ao conjunto das relações explícitas ou implícitas que um determinado texto mantém com outros (MAINGUENEAU, 2006, p. 87).

Paulo, além de fazer uma citação indireta do profeta Isaías (Is 42. 5-24) nos versículos 24 e 25, empregou, em seu discurso no Areópago de Atenas, versos de poetas gregos que, originalmente, exaltavam a Zeus, o soberano do Olimpo tais como Cleantes de Assos (331-232 a.C.) e Áratos de Soli (315-240 a.C.). O primeiro era filósofo e discípulo do fundador do estoicismo, Zenão de Cício (332-269 a.C.); o segundo, filósofo estoico e matemático grego.

A propósito, possivelmente, Toũ ... દ̇ $\sigma \mu \varepsilon^{\prime} v$ seja uma citação direta de Phaenomena, "Fenômenos" 1-5, especialmente o último verso de Áratos de Soli e do Hino a Zeus de Cleantes de Assos.

Acredita-se que o verso, que serviu de introdução ao versículo

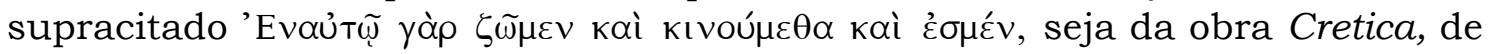
Epimênides $^{13}$ (poeta e profeta cretense de meados dos anos 600 a.C., natural de Cnossos).

\footnotetext{
${ }^{13}$ Em uma outra ocasião, Paulo utilizou, mais uma vez, os versos de Epimênides para ratificar e dar mais veracidade às suas palavras a respeito de falsos mestres cretenses, como corroboram os versículos subscritos:

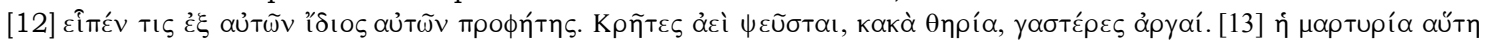

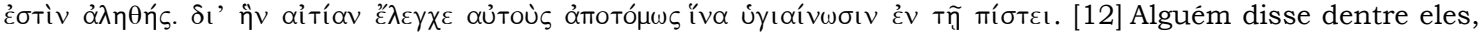
um próprio profeta deles: "Cretenses, sempre mentirosos, feras más, ventres inativos. [13] Este testemunho é verdadeiro. Por esta causa, exorta-os, severamente, para que sejam sadios na fé (Tt 1. 12-13). Paulo também

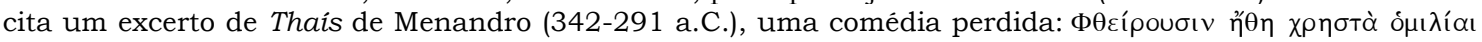

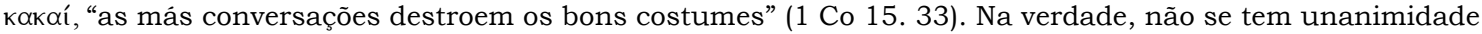
entre os estudiosos a respeito da autoria desse verso. Para tal consideração, deve-se mencionar a observação de Glad: "Muitas vezes se tem afirmado que esse provérbio é da comédia perdida Thaís de Menandro, mas
} 
Nunca é demais ressaltar a importância de um poeta na Grécia Antiga e

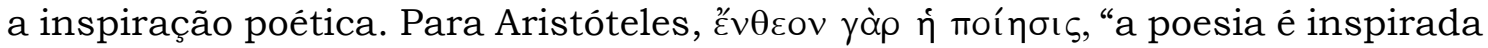
pelos deuses" (ARISTOTE. Rhétorique III, 7. 1408 b 17-19). Já Demócrito dá o seguinte testemunho: поı

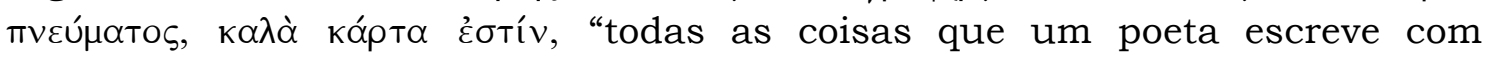
entusiasmo e sopro sagrado são, certamente, belas" (fr. D12).

Desse modo, o poeta, entre os gregos antigos, era, por muitos, considerado como um ser sagrado, que falava belas coisas, por meio de uma

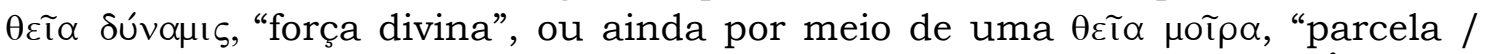
privilégio divino", e não por uma દ̇mı d; 533 e; 534 b, c, d).

Assim, a criação poética não dependia da racionalidade do homem para a sua realização. Convém lembrar, ainda, o poeta Homero e suas famosas invocações à Mou sa (Moûsa), Deusa em seus versos épicos (HOMERO. Iliada I, 1-2; II, 484-494). Homero, aliás, destaca que a Musa inspirava o aedo Demódoco (HOMERO. Odisséia VIII, 72-77).

Rowe destaca que, no discurso do Areópago, a fala de Phaenomena de Aratus e outras alusões são removidas da moldura interpretativa original e situadas em outra moldura, que se estende de Gênesis 1 até a ressurreição de Jesus no último dia (í $\mu \varepsilon_{\rho} \alpha$, vers. 31) (ROWE, 2009, p. 40).

Eis, por exemplo, os versos originais de abertura com invocação a Zeus do poeta Áratos de Soli14:

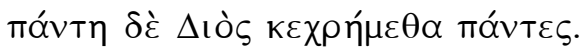

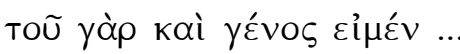

(ARATUS SOLENSIS. Phaenomena 4-5)

Em todas as partes, todos temos necessidade de Zeus.

Também, com efeito, somos descendência dele.

Seguem-se, agora, os versos subscritos de Cleantes de Assos:

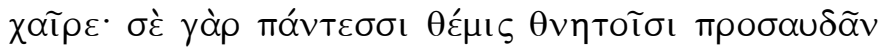

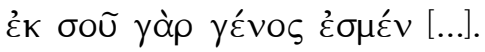

(CLEANTHES. The Hymn of Cleanthes, 4-5)

Salve! Pois é costume a todos os mortais dirigir-te a palavra. Com efeito, somos tua descendência.

No caso, a citação paulina de versos pertencentes à literatura grega funciona como um testemunho de um dizer, uma vez que se refere a declarações de outrem, para, nas palavras de Charaudeau, "provar a veracidade de alguma coisa, para constatá-la, ou para destacar sua exatidão" (CHARAUDEAU, 2010, p. 240).

Mckenzie pontua que "o discurso de Paulo não foi pronunciado no habitual estilo Paulino, mas representou um esforço para falar à maneira dos filósofos gregos" (MCKENZIE, 1983, p. 71).

Interessante destacar que o apóstolo, em uma de suas epístolas aos corintios, disserta a respeito de sua estratégia evangelística:

Robert Renehan mostrou que essas palavras "originalmente, apareceram numa tragédia, provavelmente, de Euripides" (GLAD apud SAMPLEY, 2008, p. 20).

14 Ver também: CLEANTHES. The Hymn of Cleanthes, 15-19. 


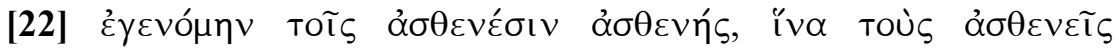

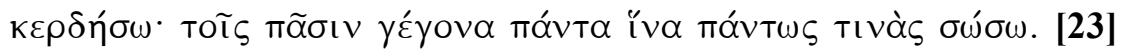

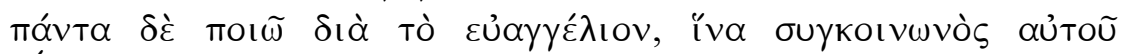

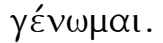

[22] Fiz-me de frágil para os frágeis, para que eu conquistasse os frágeis, fiz todas as coisas para todos, para que, por todos os meios, eu salvasse alguns. [23] Ora, faço todas as coisas por causa do evangelho, para que eu me torne seu co-participante (1 Co 9. 22-23).

Após Paulo fazer as citações de poetas gregos, ele emprega mais uma vez a comparação, dessa vez, subjetiva que é a comparação por analogia mais ou menos imagética (CHARAUDEAU, 2010, p. 238). Na verdade, Paulo, de modo indireto, estava comparando o "Deus Desconhecido", que não era obra de nenhum artífice e nem de imaginação humana (vers. 29), aos deuses do panteão grego.

\section{Fim: Anuncia o último momento da argumentação ou de uma parte dela}

Paulo passa de um tópico ao outro, empregando a partícula de nuance consecutiva oûv, "por conseguinte", finalizando sua argumentação.

Novamente, há a definição de um ser com a presença de verbos que

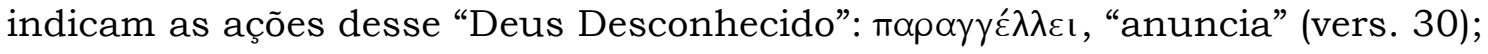

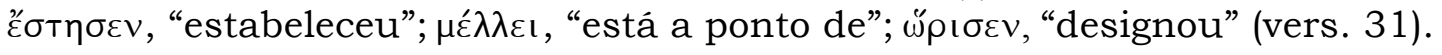

Sublinhe-se que, na parte final de seu discurso, o apóstolo faz referência, indiretamente, a um varão que foi ressuscitado pelo "Deus Desconhecido". Ora, esse "varão" seria Jesus Cristo (At 17. 30-31).

Parece que o discurso foi interrompido por causa da zombaria, quando ouviram a respeito da ressurreição (vers. 32). A propósito, Mack destaca que a ideia da ressurreição violava a sensibilidade helênica, uma vez que se tratava de uma ideia nova (MACK, 1994, p. 208).

\section{Notas Conclusivas}

A lingua é, de um modo geral, coletiva, todavia, cada indivíduo tem suas particularidades, preferências linguísticas. Então, as estratégias de construção de um discurso - citações, seleções lexicais, paralelismos, perguntas retóricas, comparações, operadores argumentativos ... - têm por escopo a transmissão de opinião(ões) do enunciador a respeito de algum assunto e conseguir uma aproximação com o seu(s) destinatário(s), de modo a criar uma cumplicidade entre ambos, para que o(s) destinatário(s) também seja seu "coenunciador".

Paulo extraiu o seu proêmio do "louvor", do "elogio" a seu público (At 17. 22) logo no início de sua argumentação, para obter a simpatia entre ele e os ouvintes; assim sendo, ao iniciar a sua argumentação, o apóstolo faz um elogio, almejando lhes despertar alguns má $\theta \eta$, "as disposições, sentimentos" (vers. 16),

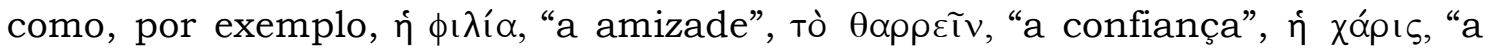
benevolência".

A princípio, pode parecer estranho tal elogio, uma vez que o relato dos Atos informa que ele ficou indignado em face da idolatria da cidade (At 17. 16). Mas apesar disso, em nenhum momento, ele desrespeitou os ouvintes, qualificando-os de "idólatras" ou de "adoradores de falsos deuses", mas os

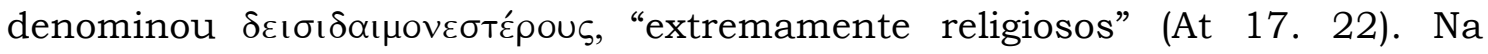


verdade, Paulo tinha consciência de que os gregos, apesar de não possuírem as mesmas crenças religiosas que ele, era um povo extremamente religioso, cultuando e crendo nos deuses que consideravam verdadeiros.

O apóstolo - valendo-se de sua vasta cultura, tanto judaica quanto helênica -, constrói também o seu ท̂ં0os, isto é, a apresentação de si, tendo em vista as $\delta o ́ \xi \alpha$, "os valores, as crenças", de seu público ateniense.

A apresentação de si do apóstolo revelou ser ele um homem bem intencionado para com seus ouvintes, portador de $\phi \rho o ́ v \eta \sigma ı \varsigma$, "prudência, sensatez". Pode-se dizer também que o missionário, ao fazer referência à cultura peculiar dos atenienses, toca nos afetos ( $\pi \alpha ́ \theta \eta)$ desse povo, mostrando que ele

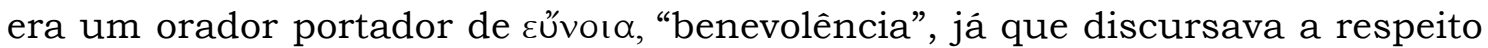
do "Deus Desconhecido", mostrando quem era, na verdade, essa Divindade, a quem os atenienses adoravam, mas não estavam muito bem informados a seu respeito. Na verdade, o "Deus Desconhecido" era superior as outras divindades do panteão helênico, sendo o verdadeiro "Senhor do Universo" (At 17. 24).

Possivelmente, Paulo sabia da importância da figura de um poeta e da influência de seus versos para o público grego. O religioso tinha consciência que ali havia gregos que ainda consideravam os poetas como seres inspirados, como "portadores da revelação divina".

$\mathrm{O}$ apóstolo, em nenhum momento, citou nomes de profetas israelitas e nem excertos das sagradas escrituras judaicas (de modo direto), para obter o respeito e a atenção de seus ouvintes.

Assim sendo, sempre que podia, Paulo empregava citações diretas, isto é, "discursos relatados", um procedimento retórico, como uma espécie de fonte da verdade, ou seja, um testemunho confiável, uma vez que essas referências estavam vinculadas a uma determinada cultura, a um passado comum, peculiar aos membros de um determinado grupo. Desse modo, o apóstolo não desprezou a cultura de seu público, dialogando com as peculiaridades desses povos, sempre que lhe era oportuno e necessário, para fundamentar a sua argumentação, para dar mais veracidade às suas palavras.

Paulo sabia que o seu público se constituía tanto de pessoas muito religiosas quanto de filósofos estóicos e epicureus, pois ele fora confrontado por esses dois últimos grupos, antes de ser conduzido para discursar no Areópago (At 17. 17-18). Para tal, empregou determinados procedimentos argumentativos, a fim de alcançar a persuasão de seus ouvintes, citem-se, por exemplo: comparações, citações e definições de um ser, conforme a terminologia charaudeana.

Atestam-se, no corpus paulinum, observações a respeito da utilização adequada do $\lambda o ́$ os ( $\mathrm{Cl}$ 4. 6). Paulo colocava, em evidência, a importância de um discurso com fluidez, para que os usuários de uma língua se entendessem (1 Co 14. 10-11). Convém sublinhar que Paulo se considerava um i $\delta ı$ tịs, "uma pessoa leiga, não treinada", quanto ao seu $\lambda o ́ \gamma o \varsigma$ (2 Co 11. 6); este, por sua vez,

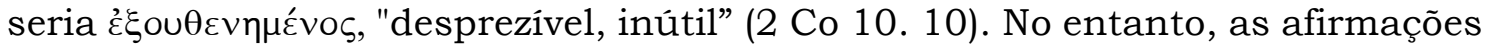

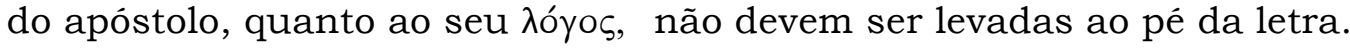

Destarte, o apóstolo conseguiu, por meio de seu discurso, persuadir alguns gregos - tanto homens quanto mulheres - que o "Deus Desconhecido", que cultuavam, era, na verdade, o verdadeiro Deus que ele anunciava (At 17. 34).

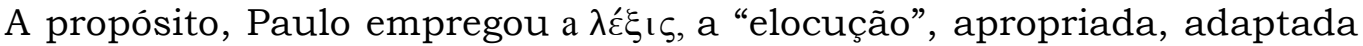
de acordo com cada tipo de público, na tentativa de obter a captatio benevolentiæe, a "boa vontade", buscando os meios, as expressões e as palavras mais adequadas, a fim de que o seu discurso fosse eficaz e, consequentemente, 
persuasivo. Na verdade, a adaptalidade ou propriedade do discurso era algo corriqueiro no mundo greco-romano.

À vista disso, conclui-se que o apóstolo contextualizou a sua mensagem, não desprezando a cultura desse povo; falou a língua dos seus ouvintes, mesmo sendo um estrangeiro, não precisou de intérprete, para alcançar a persuasão de seu público.

Não convém esquecer que Paulo aproveitava todas as oportunidades que apareciam para anunciar o evangelho (1 Co 9. 22-23; Gl 4. 13; Fp 1. 13). O missionário, em certa ocasião, destacou que a sua missão havia chegado ao fim, e que havia cumprido o seu comissionamento divino como um apologista da nova crença (2 Tm 4. 7).

Ora, Paulo, ao discursar em Atenas, vê-se, então, o encontro de dois povos: judeus e gregos. Por um lado, os judeus, além de monoteístas, tinham um "orgulho" de fazerem parte de uma "eleição divina"; de suas leis e dogmas terem sido objeto de revelação divina para eles. Por outro lado, os gregos que eram politeístas ao extremo e o seu "orgulho" não se baseava em fazer parte de um "povo eleito" por uma Divindade, mas se "orgulhavam" de seu "saber", de sua cultura seja literária, filosófica ou artística (MCKENZIE, 1983, pp. 394-395).

Assim é que o apóstolo, no decorrer de suas viagens missionárias, entrou em contato com numerosos povos e, mesmo sendo portador de cultura diferente, tentou estabelecer uma empatia com aqueles que não possuíam as mesmas convicções teológicas que ele. Desse modo, o contexto histórico e a localização espacial foram de suma importância para a compreensão de seu discurso diante dos atenienses, uma vez que o tipo de ouvinte e o quadro espacial são de grande valia, para que o orador possa construir o seu discurso e, consequentemente, a apresentação de si.

\section{Referências}

\section{Documentação Textual}

ALAND, Kurt et alli. O Novo Testamento Grego. Barueri, São Paulo: Sociedade Bíblica do Brasil, 2007.

ARATUS SOLENSIS. Phaenomena. Ed. of G. R. Mair. London: William Heinemann; New York: G.P. Putnam's Sons, 1921. Disponivel em: http://www.perseus.tufts.edu/hopper/text?doc=Perseus\%3atext\%3a2008.01. 0483. Acesso em: 27/09/2013.

ARISTOTE. Rhétorique. Texte établi et traduit par Médéric Dufour. Paris: Les Belles Lettres, 1967, Tome Premier.

Rhétorique. Texte établi et traduit par Médéric Dufour. Paris: Les

Belles Lettres, 1967, Tome Deuxième.

Rhétorique. Texte établi et traduit par Médéric Dufour e André

Wartelle. Paris: Les Belles Lettres, 1973, Tome Troisième.

DIÓGENES LAÉRCIO. Vidas de Filósofos Ilustres. Tradução de José Ortiz Sainz.Barcelona: Omega, 2008.

CLEANTHES. The Hymn of Cleanthes. Ed. of Caroline A.J. Skeel; H.J. White; J.P. Whitney. London: Society for Promoting Christian Knowledge, 1921. Disponivel

em: https://archive.org/stream/hymncleanthesgr00blakgoog\#page/n4/mode/2up . Acesso em: 28/11/2013.

DIÓGENES LAÉRCIO. Vidas de Filósofos Ilustres. Tradução de José Ortiz Sainz. Barcelona: Omega, 2008.

DIOGENES LAERTIUS. Lives of Eminent Philosophers. Ed. of R.D. Hicks. Cambridge. Harvard University Press. 1972 (First published 1925). Disponivel 
em:

http://www.perseus.tufts.edu/hopper/text?doc=Perseus\%3Atext\%3A1999.01. 0257\%3Abook\%3D2\%3Achapter\%3D11. Acesso em: 04/02/2014.

HESÍODO. Teogonia - A Origem dos Deuses. Tradução de Jaa Torrano.São Paulo: Iluminuras, 2007.

HOMERO. Iliada. Edição Bilingue. Tradução de Haroldo de Campos. São Paulo: Arx, 2003.

Odisseia. Tradução de Carlos Alberto Nunes. São Paulo: Ediouro, 1992. PLATÃO. Íon. Tradução de Victor Jabouille. Lisboa: Editorial Inquérito, 1988.

\section{Documentação Teórica}

AMOSSY, Ruth (org.). Imagens de Si no Discurso - A Construção do Êthos. São Paulo: Contexto, 2011.

BAYLLE, Anatole. Dictionnaire Grec-Français. Ed. Revista por L. Séchan e Chantraine. Paris: Hachette, 2000.

CHARAUDEAU, Patrick. Linguagem e Discurso: Modos de Organização. Tradução Ângela M. S. Corrêa e Ida Lúcia Machado. São Paulo: Contexto, 2010. FABRIS, Rinaldo. Para ler Paulo. São Paulo: Edições Loyola, 1996.

FERGUSON, John. A Herança do Helenismo. Tradução de Antônio Gonçalves Mattoso. Lisboa, Portugal: Editorial Verbo, 1973.

FORBES, Christopher. Paulo e a Comparação Retórica. In: SAMPLEY, J. P. (org.) Paulo no mundo greco-romano: um compêndio. São Paulo: Paulus, 2008.

GRIMAL, Pierre. Dicionário da Mitologia Grega e Romana. Tradução de Victor Jabouille. Rio de Janeiro: Bertrand Brasil, 2000.

FIORIN, José Luiz. Linguagem e Ideologia. São Paulo: Ática, 2003.

HOCK, Ronald F. Paulo e a Educação Greco-Romana. In: SAMPLEY, J. P. (org.) Paulo no mundo greco-romano: um compêndio. São Paulo: Paulus, 2008.

KERBRAT-ORECCHIONI, Catherine. O Êthos Em Todos os Seus Estados. In: MACHADO, Ida Lúcia \& MELlO, Renato de (Orgs.). Análises do Discurso Hoje. Tradução de Emília Mendes et alli. Rio de Janeiro: Nova Fronteira, 2010, pp. 117-135.

KOESTER, Helmut. Introdução ao Novo Testamento. História, Cultura e Religião do Periodo Helenístico. Volume 1. Tradução de Euclides Luiz Calloni. São Paulo: Paulus, 2005.

KITTO, H.D.F. Os Gregos. Coimbra: Armênio Amado Editor, 1980.

MCKENZIE, John L. Dicionário Bíblico. Edições Paulinas. São Paulo: 1983.

MACHADO, Ida Lúcia \& MELlO, Renato de (Orgs.). Análises do Discurso Hoje. Rio de Janeiro: Nova Fronteira, 2010.

MACK, Burton L. O Evangelho Perdido: O Livro $Q$ e as Origens Cristãs. Tradução de Sérgio Alcides. Rio de Janeiro: Imago, 1994.

MAINGUENEAU, Dominique. Termos-Chave da Análise do Discurso. Belo Horizonte: Ed. UFMG, 2006.

. Análise de Textos de Comunicação. Tradução de Cecília P. de Souza-eSilva e Décio Rocha. São Paulo: Cortez, 2004.

Novas Tendências em Análise do Discurso. Tradução de Freda Indursky.

Campinas, S.P.: Pontes - Ed. da Universidade Estadual de Campinas, 1997.

MURPHY-O'CONNOR, Jeromy. Paulo, Biografia Crítica. Tradução de Bárbara Theoto Lambert. São Paulo: Edições Loyola, 2004.

PEREIRA, Maria Helena da Rocha. Estudos de História da Cultura Clássica. Lisboa:

Fundação Calouste Gulbenkian, 1993.

PERELMAN Chaïm e OLBRECHTS-TYTECA, Lucie. Tratado da Argumentação: A

Nova Retórica. São Paulo: Martins Fontes, 2005. 
REBOUL, Olivier. Introdução à Retórica. Tradução de Ivone Castilho Benedetti. São Paulo: Martins Fontes, 2004.

ROWE. C. Kavin. World Upside Down - Reading Acts in the Graeco Roman Age. New York: Oxford University Press, 2009.

RUSCONI, Carlo. Dicionário do Grego do Novo Testamento. Tradução de Irineu Rabuske. São Paulo: Paulus, 2011.

SAMPLEY, J. P. (Org.). Paulo no Mundo Greco-Romano: Um Compêndio. Tradução de Pe. José Raimundo Vidigal. São Paulo: Paulus, 2008.

TORRANO, JAA. Ouvir Ver Viver a Canção. In: HESÍODO. Teogonia - A Origem dos Deuses. Estudo e Tradução de JAA Torrano. São Paulo: Iluminuras, 2007 a, pp. 15-20.

, JAA. Musas e Poder. In: HESÍODO. Teogonia - A Origem dos Deuses. Estudo e Tradução de JAA Torrano. São Paulo: Iluminuras, 2007 b, pp. 29-37. VANOYE, Francis. Usos da Linguagem: Problemas e Técnicas na Produção Oral e Escrita. Tradução e Adaptação de Clarisse Madureira Sabóia [et al.]. São Paulo: Martins Fontes, 1986.

VINE, W. E. Dicionário Vine: O Significado Exegético e Expositivo das Palavras do Antigo e do Novo Testamento. Rio de Janeiro: CPAD, 2002. 